\title{
Dysgraphic features in motor neuron disease: a review
}

Edoardo Nicolò Aiello ${ }^{1,2}$, Sarah Feroldi ${ }^{1,2}$, Alice Naomi Preti ${ }^{3}$, Stefano Zago ${ }^{4}$, Ildebrando Marco Appollonio $1,5,6$

${ }^{1} \mathrm{PhD}$ in Neuroscience, University of Milano-Bicocca, Monza, Italy

${ }^{2}$ School of Medicine and Surgery, University of Milano-Bicocca, Monza, Italy

${ }^{3}$ Department of General Psychology, University of Padua, Padova, Italy

${ }^{4}$ U.O.C. di Neurologia, IRCCS Fondazione Ospedale Maggiore Policlinico, University of Milan, Milano, Italy

${ }^{5}$ Neurology Section, School of Medicine and Surgery, University of Milano-Bicocca, Monza, Italy

${ }^{6}$ Milan Center for Neuroscience (NeuroMI), Milan, Italy

Abstract [word count: 351/400]

Background. Motor neuron disease (MND) patients can show oral language deficits mimicking those of frontotemporal degenerations (FTD). Although dysgraphic features have been also reported within the MND-FTD continuum, their characteristics and clinical relevance are still largely unexplored.

Aims. To profile writing disorders in MND patients can help further define their cognitive semiology and thus conveys relevant clinical entailments. Therefore, this study aimed at reviewing evidence of writing impairment in MND patients. This review was implemented and reported by consulting Preferred Reporting Items for Systematic Reviews and Meta-Analyses guidelines. Qualitative/quantitative measures of writing abilities in MND patients was the primary outcome. Both group studies and case reports/series were taken into consideration. Twenty-four contributions were included out of an initial $N=83$. Potential biases in generalizing results were qualitatively controlled for by extracting background, disease-related, neuropsychological and neuroanatomofunctional secondary outcomes.

Main Contribution. Fifteen studies assessed writing abilities in Japaneses patients, whereas the remaining eight in western patients. Central dysgraphic features were reported in both neuropsychologically-impaired and -unimpaired MND patients. Phonetic/phonological 
paragraphias and morpho-syntactic errors were frequently reported. Although FTD was frequently co-occurent, neither cognitive nor language impairment fully accounted for writing impairment in some patients. By contrast, evidence of peripheral dysgraphia was scarce. Patients displaying writing deficits often presented with bulbar signs and perisylvian cortices involvement (including Exner's area and the left angular gyrus). Writing deficits proved to be associated with abnormalities in executive functioning and its neural substrates. Writing-todictation tasks as well as writing samples assessment proved to be useful to detect writing errors.

Conclusions. Dysgraphic features in MND patients might be due to dysfunctions of the graphemic buffer - and possibly the phonological route. The lexico-semantic route appeared to be less involved. However, a mixed peripheral/central involvement cannot be ruled out. In this population, executive/attentive deficits are likely to contribute to writing errors as well. Writing deficits might thus be specific of MND patients' cognitive/language impairment profile. The evaluation of writing abilities via writing-to-dictation/narrative writing tasks may be useful when assessing cognition/language in both neuropsychological-impaired and -unimpaired MND patients - especially when severe dysarthria/anarthria is present and prevents clinicians from assessing oral language.

Keywords: motor neuron disease; dysgraphia; writing; language impairment; frontotemporal degeneration; neuropsychology.

Running head: Dysgraphia in MND 
medRxiv preprint doi: https://doi.org/10.1101/2021.01.31.21250861; this version posted February 1, 2021. The copyright holder for this preprint (which was not certified by peer review) is the author/funder, who has granted medRxiv a license to display the preprint in perpetuity. It is made available under a CC-BY-NC-ND 4.0 International license.

[word count: 4661/7500]

\section{Introduction}

Motor neuron diseases (MND) are currently regarded as multi-system disorders affecting both motor and extra-motor systems [Al-Chalabi et al., 2016]. Due to both physiopathological and genetic similarities shared with frontotemporal degenerations (FTD) [Burrell et al., 2016], up to $50 \%$ of MND patients present with cognitive and/or behavioral deficits within the FTD spectrum [Pender et al., 2020].

Advances in cognitive semiology of MND patients are relevant to identify sensitive markers of cognitive impairment, which negatively influences their multi-disciplinary clinical management and their ecological functioning [Christidi et al., 2018; Huynh et al., 2020].

Language deficits mimicking those of primary progressive aphasias (PPA) [Gorno-Tempini et al., 2011] are estimated to be moderately prevalent in MND patients (35-40\%) [Strong et al., 2017]. Language dysfunctions in MND patients affect phonological, lexico-semantic and morpho-syntactic components, as well as connected speech and frontally-mediated communicative functioning [Pinto-Grau et al. ,2018].

Although language in MND patients has been mainly investigated in the oral modality, writing deficits have been also reported [Pinto-Grau et al. ,2018] - mostly in Japanese patients, whilst rarely in western languages [Ichikawa et al., 2012]. The features of acquired writing disorders in MND patients are nonetheless still largely unknown.

The differences between the Japanese writing system and those of western languages - with respect to both linguistic aspects and neuro-cognitive underpinnings [Sakurai, 2019] - make it challenging to integrate available evidence. Indeed, as opposed to western writing systems that are mostly alphabetic, Japanese written language encompass both a phonogram- (kana) and an ideogram-based (kanji) system - which underlie different neuro-cognitive mechanisms and can be thus selectively damaged [Ichikawa et al., 2012; Sakurai, 2019]. If compared to alphabetic systems, kana words can be paralleled by words with a regular phoneme-to-grapheme correspondence (and are thus more likely to be processed via a phonological route), whereas kanji words by irregular words - as having their phonetics/phonology associated with their semantics (being thus more likely to be processed via a lexico-semantic route) [Sakurai et al., 1997; Purcell et al., 2011; Ichikawa et al., 2012; Sakurai, 2019]. As far as kana and kanji 
writing is concerned, both generalized and selective deficits have been frequently reported in neurological disorders affecting perisylvian language networks [Sakurai, 2019]. Therefore with regard to central writing disorders, to adapt western nosography (e.g., phonological vs. surface dysgraphia) to Japanese writing deficits is not trivial [Sakurai et al., 1997]

To profile writing disorders in MND patients is also diagnostically relevant since: a) the detection of language deficits is sufficient in order to classify those patients as cognitively impaired [Strong et al., 2017]; b) writing is useful to assess language functioning in severely dysarthric/anarthric patients [Ichikawa et al., 2012].

Aim of the present work was thus to review evidence reporting writing impairment in MND patients in order to draw cross-linguistically valid inferences regarding its features.

\section{Methods}

\subsection{Search strategy}

Preferred Reporting Items for Systematic Reviews and Meta-Analyses guidelines [Moher et al. 2009] were consulted in order to implement and report the present review. The following search terms were entered into Scopus and PubMed databases on October $19^{\text {th }}, 2020$ : "amyotrophic lateral sclerosis" OR "motor neuron disease" in combination with (AND) "writing error*" OR "writing disorder*" OR "writing dysfunction*" OR "writing deficit*" OR "writing error*" OR "dysgraphi*" or "agraphi*". Fields of search were the title, the abstract and the key-words in Scopus, whereas the title and the abstract in PubMed.

\subsection{Inclusion criteria and outcomes}

For a contribution to be included, a) writing abilities had to be assessed (via either qualitative or quantitative methods) b) in MND patients. The following primary outcomes were extracted: features of writing impairment; writing assessment methods; kana and/or kanji errors (for Japanese contributions); neural correlates of writing abilities. Review and meta-analysis were excluded. Both group studies and case reports/case series, as well as both longitudinal and cross-sectional studies, were taken into consideration. The following secondary outcomes were extracted (when applicable): patients' demographics (age, sex, education, language) and clinical 
features (phenotype [Chiò et al., 2011], disease duration, presence of bulbar signs, motorfunctional outcome [Cedarbaum et al., 1999]); neuropsychological (NPs) vs. motor onset [Mioshi et al., 2014]; presence of dementia (and type); presence of cognitive and/or behavioral impairment (CI/BI; and type); features of oral language impairment (LI); neural measures.

A qualitative method of writing assessment (e.g., evaluation of everyday-life writing samples) was assumed if not otherwise stated. A motor onset was assumed if there was not an explicit statement regarding cognitive/behavioral deficits as the presenting symptoms. When a generic diagnosis of dementia was posed, behavioral variant of FTD (bvFTD) was assumed if NPs deficits appeared to fall under those described in Rascovsky et al.'s (2011) diagnostic criteria. Neural correlates of writing abilities were taken into account only when correlations with writing measures were explicitly investigated.

\subsection{Bias assessment}

The vast majority of the aforementioned secondary outcomes [see 2.2] were taken into account in order to minimize potential biases in generalizing results.

With regard to demographics, since writing abilities are learned and sharpened during school years, low levels of educational attainment might lead to a misinterpretation of writing difficulties. Moreover, taking into consideration different languages might prevent from inferring cross-linguistically generalizable conclusions.

Regarding neurological outcomes, the occurrence of bulbar signs (and thus possibly dysarthria/anarthria) might lead to an overestimation of writing disorders (if present) since language functioning can be solely/are preferably assessed in the written modality [Cobble, 1998].

From a NPs standpoint, both the occurrence of extra-linguistic CI/BI and co-morbid nonaphasic dementia might contribute to writing disorders [Graham, 2000]. Therefore, it was of interest to determine whether deficits in domains other than writing abilities could to an extent account for dysgraphic features [Ardila \& Surloff, 2006]. 


\subsection{Study selection process}

Study selection process is shown in Figure 1. $N=76$ contributions were identified through the first level search strategy and were screened within the title and abstract; among them, $N=37$ were excluded based on inclusion criteria. The remaining $N=39$ were selected for further eligibility - along with $N=7$ contributions that were identified through hand-search and judged as being likely to meet inclusion criteria.

After removing duplicates and again applying inclusion criteria, $N=22$ contributions were excluded and $N=23$ were selected for inclusion.

$N=4$ contributions were available in Japanese, and were thus included by only taking into account the abstract and possibly other sections available in English.

Insert Figure 1 about here

\section{Results}

\subsection{Outcomes overview}

Extracted outcomes are summarized in Table 1; an overview of background variables is reported in Table 2. Only $N=5$ contributions were group studies, whereas all the remaining were either case reports or case series. The majority of studies investigated writing abilities in Japanese patients; the remaining assessed western patients. The most prevalent phenotype across studies was amyotrophic lateral sclerosis (ALS); several studies adopted the generic label "MND". Patients with bulbar signs were highly represented. The vast majority of studies included patients showing either dementia or NPs impairment, whereas only 4 studies reported unimpaired patients.

Insert Tables 1 and 2 about here 


\subsection{Group studies}

\subsubsection{Group studies: western languages}

Piquard et al. (2006) and Zago et al. (2008) assessed writing abilities in French and Italian primary lateral sclerosis (PLS) patients, respectively - comparing them to healthy controls (HC). Although both cohorts did not present with FTD or overt NPs impairment, central dysgraphic features were detected via writing-to-dictation tasks (of words/non-words/sentences) as either morpho-syntactic errors [Piquard et al., 2006] or phonetic/phonological paragraphias [Piquard et al., 2006; Zago et al., 2008]. Zago et al. (2008) also reported phonetic/phonological paragraphias in writing of non-words with preformed letters. The nature of writing deficits in Zago et al.'s (2008) contribution suggested a dysfunction of the graphemic buffer. Furthermore, the Authors found writing impairment to be associated with bulbar dysfunction - thus hypothesizing that spelling errors might have been accounted for by a rehearsal deficit due to the absence of motor feedback from the phono-articulatory system.

\subsubsection{Group studies: Japanese language}

Tsuji-Akimoto et al. (2010) compared non-demented ALS patients to HCs on several NPs measures. Writing abilities were assessed via writing to dictation of kana and kanji characters, as well as by a writing errors index (WEI) computed from written description outputs. The WEI encompasses both phonetic/phonological and lexico-semantic paragraphias, as well as morphosyntactic errors. At a group level, patients showed auditory comprehension and executive functioning (EF) deficits, as well as difficulties in writing kanji characters to dictation and a higher WEI than HCs. At an individual level, errors in writing to dictation of both kana and kanji characters were detected in patients. Interestingly, even those patients who did not show any errors when writing to dictation made both kana and kanji errors (of either phonetic/phonological, lexico-semantic or morpho-syntactic type) in written descriptions. Across tasks, the omission of kana letters (OKL) and a missing subject were found to be the most prevalent type of errors regarding phonetic/phonological and morpho-syntactic components, respectively. It is worth noting that the Authors described phonologically-plausible 
medRxiv preprint doi: https://doi.org/10.1101/2021.01.31.21250861; this version posted February 1, 2021. The copyright holder for this preprint

errors in both kana and kanji writing - thus suggesting surface dysgraphia. Moreover, the WEI was found to be mildly associated with disease duration. Yabe et al. (2012) again found that the WEI [Tsuji-Akimoto et al., 2010] was able to discriminate ALS patients from HCs, additionally showing that it was related to bilateral right-greater-than-left anterior cingulate cortex (ACC) dysfunction as assessed by positron emission tomography (PET). The Authors thus hint at EF deficits possibly accounting for writing errors at least to an extent. It is nonetheless worth noting that Yabe et al.'s (2012) cohort did present with mild only EF deficits. Recently, Sakurai et al. (2020) investigated the association between language functioning and neurofunctional measures (SPECT) in a cohort of 37 ALS patients. Phonological, lexico-semantic and morphosyntactic dysfunctions, as well as reading and writing deficits were detected. Among different language measures, a written description task yielded the highest frequency of impairment $(51.4 \%)$ and proved to be related to left both cortical and sub-cortical angular structures functioning - which are acknowledged to be involved in writing abilities [Sakurai et al., 2007]. When comparing ALS patients who displayed writing errors to those who did not, the former had lower educational attainment, reading scores as well as decremented inferior frontal, left supramarginal and bilateral parietal perfusion. Moreover, it is worth noting that age and age at onset were associated with writing errors.

\subsection{Case series}

\subsubsection{Case series: western languages}

Ferguson \& Boller (1977) described two non-demented English ALS patients showing phonetic/phonological paragraphias, morpho-syntactic errors and perseverations in spontaneous writing. Both patients developed bulbar signs. Although Case 1 was suspected to show also Gerstmann syndrome-like symptoms and presented with mild fronto-parietal neuropathological changes at post-mortem examination, Case 2 was not reported to present with overt NPs deficits. Case 1 also showed allographic preferences (uppercase) as the disease progressed. Duffy et al. (2006) similarly found spelling and morpho-syntactic errors in 4 out of 7 English MND patients - which nevertheless presented with apraxia of speech (AoS). Three out of the aforementioned 4 patients also presented with either bvFTD or PPA. 
medRxiv preprint doi: https://doi.org/10.1101/2021.01.31.21250861; this version posted February 1, 2021. The copyright holder for this preprint

\subsubsection{Case series: Japanese language}

Satoh et al. (2009) assessed writing abilities in 16 neuropsychologically-spared ALS patients by means of quantitative written language tests [Shewan \& Kertsez, 1980; WAB Aphasia Test Construction Committee, 1986] and a task of counting of morae - i.e., the phonological units of kana words [Mishima et al., 2000]. Kana errors (morae miscounting and OKL) were found in 3 patients, whereas kanji errors in four; two patients simultaneously showed both kana and kanji errors. None of the patients showed morphological cortical abnormalities (magnetic resonance imaging, MRI), whereas single-photon emission computed tomography (SPECT) revealed bilateral frontal hypo-functioning in a patient presenting with both kana and kanji errors.

Ichikawa et al. (2008a) retrospectively assessed spontaneous writing samples and clinical features of 7 demented ALS patients. Patients presumably presented with bvFTD and showed anosognosia; 6 out of 7 and had bulbar-onset ALS. Writing errors were found in 6 patients: they showed both phonological/morphological kanji paragraphias (i.e., wrote a kanji character sharing either phonological or morphological similarities with the target) and kana errors (OKL, substitutions and perseverations); kana-kanji dissociations were also detected. Although oral LI could not be ruled out in 6 patients due to anarthria, it is worth noting that the patient whose oral output was intelligible and unimpaired still showed with kanji errors on a written description task. Bilateral frontotemporal atrophy (MRI) and hypo-functioning (SPECT) were detected in all patients - with a left predominance being found in three. The same group [Ichikawa et al., 2008b] similarly reported both kana and kanji errors in a retrospective cohort of bulbar-onset ALS patients, the majority of whom (10/15) either were demented (presumably presenting with bvFTD) or presented with BI. Thirteen out of 15 patients showed phonological/morphological kana paragraphias (including morpho-syntactic errors), whereas phonological/morphological kanji paragraphias were detected in 5 patients only; one patient showed only kanji errors. Furthermore, the Authors underlined that writing errors were also found in 2 non-anarthric patients who neither clinically showed oral LI nor CI/BI. The Authors subsequently described in more detail the 2 patients in a separate contribution [Ichikawa et al., 2010b]. Both patients presented with dysarthria. Phonological and lexico-semantic components 
medRxiv preprint doi: https://doi.org/10.1101/2021.01.31.21250861; this version posted February 1, 2021. The copyright holder for this preprint (which was not certified by peer review) is the author/funder, who has granted medRxiv a license to display the preprint in perpetuity.

It is made available under a CC-BY-NC-ND 4.0 International license .

of oral language were reported to be unimpaired, although both kana and kanji errors were detected both on a writing-to-dictation task and in spontaneous writing. Copy of letters was preserved; furthermore, a diagnosis of peripheral dysgraphia was ruled out. At structural and functional neuroimaging, left-greater-than right frontotemporal and parietal involvement was detected.

In a subsequent study, Ichikawa et al. (2010a) retrospectively investigated the association between writing errors and measures of cortical atrophy based on computer tomography (CT) [Evans, 1942; Frisoni et al., 2002] in 14 ALS patients. The majority of patients presented with bulbar/pseudobulbar signs at onset, and the presence of oral LI was either not detected or not assessable; seven patients showed bvFTD. Twelve patients showed kana errors, 8 of whom additionally presented with kanji errors - which nonetheless were not detected in isolation. The percentages of total and kana errors were found to be related to measures of frontal atrophy [Evans, 1942], whereas measures of temporal atrophy [Frisoni et al., 2002] were associated with kanji errors. Associations between the occurrence of bvFTD and writing errors were also reported. The same group further investigated the aforementioned anatomo-clinical associations also from a longitudinal standpoint [Ichikawa et al., 2011a]: writing abilities of six neuropsychologically-spared ALS patients were put in relation to two over-time-repeated CTbased measures of cortical atrophy. Five patients showed kana errors, 2 of whom also presented with kanji errors. Progression rate of rostral atrophy was found to be associated with both total and kana errors, whereas caudal atrophy proved not to be related to dsygraphic features; no associations were found between longitudinal atrophy measures and kanji errors separately. Anarthria prevented the Authors from stating whether oral LI was present at the time of the second CT measurement.

\subsection{Case reports}

\subsubsection{Case reports: western languages}

Luchelli \& Papagno (2005) described a patient presenting with primary progressive AoS who later developed MND. Overt NPs impairment/dementia was not detected. Phonetic/phonological paragraphias appeared to be highly frequent in several tasks; morphosyntactic errors were also noted. 
medRxiv preprint doi: https://doi.org/10.1101/2021.01.31.21250861; this version posted February 1, 2021. The copyright holder for this preprint (which was not certified by peer review) is the author/funder, who has granted medRxiv a license to display the preprint in perpetuity.

It is made available under a CC-BY-NC-ND 4.0 International license .

Östberg \& Bogdanović (2011) described a Swedish patient presenting with semantic dementia (SD) who then developed lower motor neuron-predominant ALS. Severe impairment of semantic and lexical components was detected at oral language assessment: temporal rightgreater-than-left abnormalities were detected at both morphological and functional neuroimaging, as well as at neuropathological examination. The Authors report that the patient showed both surface dyslexia and surface dysgraphia. Mehrabian et al. (2018) described a Bulgarian ALS-FTD patient carrying C9orf72 hexanucleotide repeat expansion who showed phonetic/phonological paragraphias on written naming. These dysgraphic features did reportedly worsen over time. The patient presented with multi-domain CI but was not classified as aphasic. MRI revealed bilateral left-greater-than-right frontal atrophy. Both the aforementioned cases showed bulbar signs. Vonk et al. (2020) recently reported a case of SD who reportedly developed ALS over a 14-years disease course. Among language dysfunctions, surface dysgraphia (along with surface dyslexia) was described. Although bilateral frontotemporal atrophy developed over time, in the first stages of the disease right-greater-thanleft temporal atrophy was evident.

\subsubsection{Case reports: Japanese language}

Dysgraphic features have been described in patients with MND and co-morbid PPA either progressive non-fluent aphasia (PNFA) [Hyodo et al.,2002] or SD [Kito et al., 2010]. Hyodo et al.'s (2002) patient presented with PNFA and MND and reportedly showed phonetic/phonological paragraphias, as well as morpho-syntactic errors and perseverations in writing. Abnormalities were detected in left temporal and bilateral parietal cortices (MRI, SPECT). Kito et al. (2010) described a patient with SD who then developed MND. It is worth noting that difficulties in writing kanji were reported among the first cognitive symptoms. Kana errors appeared too, and dysgraphic features reportedly worsened over time. Bilateral leftgreater-than-right frontal and rostro-temporal atrophy (MRI) and hypo-functioning (SPECT) was detected - and progressed over time. Both the aforementioned patients showed bulbar signs during the course of the disease.

Ishihara et al. (2010) described a neuropsychologically-impaired non-aphasic ALS patient who still reportedly showed mild-to-moderate phonological, lexico-semantic and morphosyntactic impairment. Dysexecutive symptoms appeared to be prominent; bulbar signs were 
medRxiv preprint doi: https://doi.org/10.1101/2021.01.31.21250861; this version posted February 1, 2021. The copyright holder for this preprint

present. Right-greater-then-left rostro-temporal and bilateral frontal atrophy, as well as bilateral frontotemporal hypo-functioning, were detected at morphological (MRI) and functional (SPECT) neuroimaging, respectively. It is of great interest that particularly prominent histopathological abnormalities happened to be found in the caudal portions of the inferior frontal gyrus bilaterally - i.e., the so-called Exner's area, which is acknowledged to be involved in writing abilities [Roux et al., 2009].

Ichikawa et al. (2011b) translated into English a 1893 Japanese case report [Watanabe, 1893], which described a patient presenting with bulbar palsy and progressive muscular atrophy who later developed dysgraphic features and disinhibited traits. Receptive language was reportedly preserved; severe dysarthria prevented the Author from assessing productive oral language. Both kanji and kana errors were reported - the latter happening to be more prevalent. Writing errors were detected both when the patient was asked to provide answers by writing and on writing-to-dictation tasks; copy and writing of automated series was preserved.

Maeda et al. (2015) reported a patient with progressive bulbar palsy who also presumably presented with bvFTD. Although severe EF deficits are described, the patient was reported to show neither overt oral LI nor dyslexia. The patient was able to write single kana characters, whereas presented with kana errors (OKL, substitution and morpho-syntactic errors) in writing words and sentences. The patient was reported to show kana phonetic/phonological paragraphias when writing text messages on her mobile phone. Kanji errors were nonetheless less frequent. Frontal atrophy/hypo-functioning was detected (MRI/SPECT); additionally, SPECT examination revealed right parietal hypo-functioning. Exner's area was also reported to be involved (SPECT). The patient reportedly developed Gerstmann syndrome over the course of the disease.

Cui et al. (2016) described an ALS patient presumably presenting with bvFTD with evidence of frontal and right-greater-then-left temporal atrophy (MRI). Although multi-domain CI was present, oral language assessment did not reveal major deficits. With regard to written language, copy was spared, whereas phonetic/phonological and morphological errors were present in writing-to-dictation and written naming tasks.

\section{Discussion}


medRxiv preprint doi: https://doi.org/10.1101/2021.01.31.21250861; this version posted February 1, 2021. The copyright holder for this preprint

The present results suggest that central writing deficits may be a feature of MND patients' cognitive dysfunction profile. Indeed, evidence suggestive of peripheral involvement appeared to be scarce, as well as, if present, to co-occur with central dysgraphic features [e.g., Ferguson \& Boller, 1977]. Consistently, copying abilities often happened to be preserved [e.g., Ichikawa et al., 2011b]. However, it has to be noted that both central and peripheral involvement has been described in progressive dysgraphic syndromes [Graham et al., 1997] - this suggesting that a mixed peripheral/central underpinning should not be ruled out in MND patients either. Finally, it cannot be excluded that sthenic deficits in hand muscles might contribute to an extent to writing difficulties in this population [Cedarbaum et al., 1999].

Phonetic/phonological paragraphias appeared to be the most prevalent features of writing impairment in both eastern and western MND patients. Despite morpho-syntactic errors being also moderately frequent, they often happened to be due to spelling errors (e.g., kana postpositions in Japanese) [Tsuji-Akimoto et al., 2010]. Therefore, it can be hypothesized that the graphemic buffer might be involved - possibly along with the phonological route [Zago et al., 2008]. Although either a diagnosis of surface dysgraphia [e.g., Östberg \& Bogdanović, 2011] or evidence suggestive of it (e.g., phonologically-plausible errors) [e.g., Tsuji-Akimoto et al., 2010], have been also reported, the lexico-semantic route appeared to be less involved than the phonological one. Moreover, although kanji errors (possibly due to lexico-semantic route impairment) have been also frequently reported in both demented and non-demented MND patients, kana errors (possibly due to phonological route/graphemic buffer impairment) have been more consistently detected.

Extra-linguistic predictors might also contribute to dysgraphic features in MND patients in particular, those related to EF. Indeed, dysexecutive symptoms as well as frontal-type dementia have been proved to be associated/to co-occur with writing errors in MND patients [e.g., Ichikawa et al., 2010a; Tsuji-Akimoto et al. 2010]. Moreover, with regard to the nature of dysgraphic features, perseverations themselves might in turn hint at EF being impaired [e.g., Ferguson \& Boller, 1977; Hyodo et al., 2002]. EF deficits as contributing to writing errors appears also to be supported as far as neural correlates are concerned - since frontal cortices often appeared to be involved in MND patients showing dysgraphic features [e.g., Yabe et al., 2012].

From a clinical standpoint, it is of interest to note that: 1) writing errors happened to be described in patients at relatively early stages of the disease (as far as disease duration and 
medRxiv preprint doi: https://doi.org/10.1101/2021.01.31.21250861; this version posted February 1, 2021. The copyright holder for this preprint

functional impairment are concerned) [e.g., Satoh et al., 2009; Tsuji-Akimoto et al., 2010; Sakurai et al., 2020]; 2) writing impairment has been found to progressively worsen over the course of the disease [e.g., Ichikawa et al., 2011]. Thereupon, writing errors might be regarded as an early marker of cognitive decline in MND patients.

The present review would provide empirical support for spelling tasks being included in MND-specific cognitive screening instruments [Woolley et al., 2010; Abrahams et al., 2014]. Moreover, since writing errors happened to be frequently detected by assessing writing samples , it might be useful to administer either spontaneous or non-spontaneous narrative writing tasks [e.g., Catricalà et al., 2017] in order to assess writing abilities in MND patients [Sakurai et al., 2020]. Writing-to-dictation tasks of words, non-words and sentences also appeared to be able to detect writing errors in MND patients - and thus might also be included [e.g., Zago et al., 2008].

Dysgraphic features have been frequently described in non-demented MND patients who either did not present with NPs impairment [e.g., Satoh et al. 2009] or showed mild CI/BI [e.g., Tsuji-Akimoto et al., 2010]. Similarly, writing impairment has been also reported in nonaphasic MND patients who either did not show oral LI [e.g., Piquard et al., 2006] or showed only mild language deficits [e.g., Zago et al., 2008]. With respect to this latter finding, it is worth mentioning that oral LI in non-aphasic patients was found not to mirror the nature of writing deficits [Tsuji-Akimoto et al., 2010]. Therefore writing deficits might represent a specific feature of MND patients' profile [e.g., Ichikawa et al., 2008b]. This latter assertion also seems to be supported by evidence linking writing errors to abnormalities in cortical regions acknowledged to be specifically involved in writing (e.g., Exner's area) [e.g. s Ishihara et al., 2011].

Moreover, it is noteworthy that varying degrees of severity in writing impairment were reported - ranging from occasional writing errors in neuropsychologically-unimpaired patients [e.g., Satoh et al., 2009] to a full-blown dysgraphia in patients with co-morbid PPA [e.g., Hyodo et al., 2002]. This latter finding suggests that, in MND patients, dysgraphic features may occur along a continuum - similarly to other FTD-like NPs deficits [Strong et al., 2017]

Nonetheless, it has to be noted that left frontotemporal cortices have been systematically found to be involved in both demented and non-demented MND patients presenting with writing errors [see Tab. 1] - this hinting at perysilvian language networks abnormalities also possibly contributing to them [Purcell et al., 2011]. Interestingly, some contributions reported right-greater-than-left temporal involvement in neuropsychological-impaired/demented MND 
medRxiv preprint doi: https://doi.org/10.1101/2021.01.31.21250861; this version posted February 1, 2021. The copyright holder for this preprint

patients showing dysgraphia [Ishihara et al., 2011; Östberg \& Bogdanović, 2011; Cui et al., 2016; Vonk et al., 2020]. As suggested by Cui et al.'s (2016), the latter finding might hint at dysgraphia possibly being a feature of MND patients presenting with the so-called right temporal variant of FTD [Coon et al., 2012; Ulugut Erkoyun et al., 2020].

Interestingly, parietal involvement along with suspected Gerstmann syndrome has been occasionally reported in MND patients presenting with peripheral/central dysgraphic features [Ferguson \& Boller, 1977; Maeda et al., 2015; Sakurai et al., 2020]. It can be thus hypothesized that also cognitive processes relying on left parietal regions might contribute to writing deficits in this population [e.g., Sakurai et al., 2007].

The vast majority of contributions reported that MND patients showing dysgraphic features developed bulbar signs over the course of the disease. This may support the general notion that cognitive/language deficits in MND patients might be more frequent when neurodegeneration has spread to bulbar regions [Chiò et al., 2019; Shellikeri et al.,2019]. It can be postulated that to evaluate writing abilities may be particularly useful when assessing bulbar-plus MND patients' cognitive/language profile. Moreover, writing also represents the only modality through which both language and several cognitive functions can be assessed in severely dysarthric/anarthric patients. As previously mentioned [see 2.3], this latter assertion can as well be regarded as a limitation of the present review - since it might have led to an overestimation of the prevalence of writing disorders in this population. On the other hand, for the same reason, severe dysarthria/anarthria might have led to an underestimation of co-morbid NPs deficits [see 2.3].

It may be worth noting that the vast majority of the studies that were included reported dysgraphic features in MND phenotypes involving either only upper or both upper and lower motor neurons (e.g., PLS and ALS). Only one study reported dysgraphia in a patient affected with SD and co-morbid LMND [Östberg \& Bogdanović, 2011]. It can be therefore hypothesized that writing deficits, as well as cognitive impairment in general, might be more prevalent when upper motor neuron dysfunction is present - due to a greater degree of cortical involvement [Aiello et al., 2020].

The present work is of course not free of limitations. First, as previously stated [see 2.3], it is challenging to compare western to Japanese taxonomy when it comes to dysgraphia [Purcell et al., 2011; Sakurai, 2019]. Therefore, the potential lack of homogeneity on categorizing errors might have led to distortion in interpreting results, as well as in drawing cross-linguistically 
valid inferences. Furthermore, it has to be noted that the majority of the studies that were included were case reports/case series - this implying that a comparison with HCs often lacked, as well as that high levels of between-studies variability were present with respect to both adopted methods and reported elements.

\section{Conclusions}

Central dysgraphic features were reported in both neuropsychologically-impaired and unimpaired MND patients. By contrast, evidence of peripheral dysgraphia was scarce. Phonetic/phonological paragraphias and morpho-syntactic errors were frequently reported. Although FTD was frequently co-occurring, neither cognitive nor language impairment fully accounted for writing impairment in some patients. Patients displaying writing deficits often presented with bulbar signs and left perisylvian cortices involvement (including Exner's area and the left angular gyrus). Writing deficits proved to be associated with abnormalities in executive functioning and their neural substrates. Writing-to-dictation tasks as well as writing samples assessment proved to be useful to detect writing errors.

Dysgraphic features in MND patients are likely to be due to dysfunctions of the graphemic buffer/the phonological route. The lexico-semantic route appeared to be less involved. However, a mixed peripheral/central involvement cannot be ruled out. In this population, executive/attentive deficits are likely to contribute to writing errors as well. Writing deficits might thus be specific of MND patients' cognitive/language impairment profile. The evaluation writing abilities through writing-to-dictation/narrative writing tasks may be useful when assessing cognition/language in both neuropsychological-impaired and -unimpaired MND patients - especially when severe dysarthria/anarthria is present.

Disclosure statement: The Authors report no known conflicts of interest.

Fundings: This work did not receive any specific funding. 
medRxiv preprint doi: https://doi.org/10.1101/2021.01.31.21250861; this version posted February 1, 2021. The copyright holder for this preprint (which was not certified by peer review) is the author/funder, who has granted medRxiv a license to display the preprint in perpetuity.

It is made available under a CC-BY-NC-ND 4.0 International license
. 


\section{References}

Abrahams, S., Newton, J., Niven, E., Foley, J., Bak, T. H. (2014). Screening for cognition and behaviour changes in ALS. Amyotrophic Lateral Sclerosis and Frontotemporal Degeneration, 15, 9-14.

Aiello, E. N., Sbrollini, B., Preti, A. N., Zago, S., Papagno, C., \& Appollonio, I. M. (2020, December 18). Language impairment in motor neuron disease phenotypes other than ALS: a systematic review. Annual Meeting of Milan Center for Neuroscience. https://www.neuromi2020.org/poster-session

Al-Chalabi, A., Hardiman, O., Kiernan, M. C., Chiò, A., Rix-Brooks, B., van den Berg, L. H. (2016). Amyotrophic lateral sclerosis: moving towards a new classification system. The Lancet Neurology, 15, 1182-1194.

Ardila, A., Surloff, C. (2006). Dysexecutive agraphia: A major executive dysfunction sign. International Journal of Neuroscience, 116, 653-663.

Burrell, J. R., Halliday, G. M., Kril, J. J., Ittner, L. M., Götz, J., Kiernan, M. C., Hodges, J. R. (2016). The frontotemporal dementia-motor neuron disease continuum. The Lancet, 388, 919-931.

Catricalà, E., Gobbi, E., Battista, P., Miozzo, A., Polito, C., Boschi, V., Esposito, V., Cuoco, S., Barone, P., Sorbi, S., Cappa, S.F. (2017). SAND: a Screening for Aphasia in NeuroDegeneration. Development and normative data. Neurological Sciences, 38, 1469-1483.

Cedarbaum, J.M., Stambler, N., Malta, E., Fuller, C., Hilt, D., Thurmond, B., Nakanishi, A., Bdnf Als Study Group, 1A complete listing of the BDNF Study Group (1999). The ALSFRS-R: a revised ALS functional rating scale that incorporates assessments of respiratory function. Journal of the Neurological Sciences, 169, 13-21. 
Chiò, A., Calvo, A., Moglia, C., Mazzini, L., Mora, G. (2011). Phenotypic heterogeneity of amyotrophic lateral sclerosis: a population based study. Journal of Neurology, Neurosurgery \& Psychiatry, 82, 740-746.

Chiò, A., Moglia, C., Canosa, A., Manera, U., Vasta, R., Brunetti, M., Barberis, M., Corrado, L., D'Alfonso, S., Bersano, E., Sarnelli, M.F. (2019). Cognitive impairment across ALS clinical stages in a population-based cohort. Neurology, 93, e984-e994.

Christidi, F., Karavasilis, E., Rentzos, M., Kelekis, N., Evdokimidis, I., Bede, P. (2018). Clinical and radiological markers of extra-motor deficits in amyotrophic lateral sclerosis. Frontiers in Neurology, 9, 1005.

Cobble, M. (1998). Language impairment in motor neurone disease. Journal of the Neurological Sciences, 160, S47-S52.

Coon, E. A., Whitwell, J. L., Parisi, J. E., Dickson, D. W., \& Josephs, K. A. (2012). Right temporal variant frontotemporal dementia with motor neuron disease. Journal of Clinical Neuroscience, 19, 85-91.

Duffy, J. R., Peach, R. K., Strand, E. A. (2007). Progressive apraxia of speech as a sign of motor neuron disease. American Journal of Speech-Language Pathology, 6, 198-208.

Evans, W. A. (1942). An encephalographic ratio for estimating ventricular enlargement and cerebral atrophy. Archives of Neurology \& Psychiatry, 47, 931-937.

Ferguson, J. H., Boller, F. (1977). A different form of agraphia: syntactic writing errors in patients with motor speech and movement disorders. Brain and Language, 4, 382-389.

Frisoni, G.B., Geroldi, C., Beltramello, A., Bianchetti, A., Binetti, G., Bordiga, G., DeCarli, C., Laakso, M.P., Soininen, H., Testa, C., Zanetti, O. (2002). Radial width of the temporal horn: a sensitive measure in Alzheimer disease. American Journal of Neuroradiology, 23, 35-47. 
Gorno-Tempini, M.L., Hillis, A.E., Weintraub, S., Kertesz, A., Mendez, M., Cappa, S.F., Ogar, J.M., Rohrer, J.D., Black, S., Boeve, B.F., Manes, F. (2011). Classification of primary progressive aphasia and its variants. Neurology, 76, 1006-1014.

Graham, N. L. (2000). Dysgraphia in dementia. Neurocase, 6, 365-376.

Graham, N. L., Patterson, K., Hodges, J. R. (1997). Progressive dysgraphia: Co-occurrence of central and peripheral impairments. Cognitive Neuropsychology, 14, 975-1005.

Huynh, W., Ahmed, R., Mahoney, C.J., Nguyen, C., Tu, S., Caga, J., Loh, P., Lin, C.S., Kiernan, M.C. (2020). The impact of cognitive and behavioral impairment in amyotrophic lateral sclerosis. Expert Review of Neurotherapeutics, 20, 281-293.

Hyodo, T., Ikeda, M., Ueno, S. I., Komori, K., Hokoishi, K., Fukuhara, R., Tanabe, H. (2002). A case of motor neuron disease with progressive aphasia and dementia. Brain and Nerve, 54, 713-718.

Ichikawa, H., Hieda, S., Ohno, H., Ishihara, K., Kawamura, M. (2012). Language impairment in amyotrophic lateral sclerosis from an historical review: kana and kanji versus alphabetical languages. In M. J. Strong (Ed.), Amyotrophic Lateral Sclerosis and the Frontotemporal Dementias (pp. 93-106). Oxford University Press.

Ichikawa, H., Hieda, S., Ohno, H., Ohnaka, Y., Shimizu, Y., Nakajima, M., \& Kawamura, M. (2010a). Kana versus kanji in amyotrophic lateral sclerosis: a clinicoradiological study of writing errors. European Neurology, 64, 148-155.

Ichikawa, H., Takahashi, N., Hieda, S., \& Kawamura, M. (2010b). Bulbar-onset amyotrophic lateral sclerosis (ALS) with isolated agraphia. Rinsho Shinkeigaku= Clinical Neurology, 50(2), 81-86. 
medRxiv preprint doi: https://doi.org/10.1101/2021.01.31.21250861; this version posted February 1, 2021. The copyright holder for this preprint (which was not certified by peer review) is the author/funder, who has granted medRxiv a license to display the preprint in perpetuity. It is made available under a CC-BY-NC-ND 4.0 International license .

Ichikawa, H., Koyama, S., Ohno, H., Ishihara, K., Nagumo, K., Kawamura, M. (2008a). Writing errors and anosognosia in amyotrophic lateral sclerosis with dementia. Behavioural Neurology, 19, 107-116.

Ichikawa, H., Ohno, H., Murakami, H., Ohnaka, Y., Kawamura, M. (2011a). Writing error may be a predictive sign for impending brain atrophy progression in amyotrophic lateral sclerosis: a preliminary study using X-ray computed tomography. European Neurology, 65, 346-351.

Ichikawa, H., Miller, M.W., Kawamura, M. (2011b). Amyotrophic lateral sclerosis and language dysfunction: Kana, Kanji and a prescient report in Japanese by Watanabe (1893). European Neurology, 65,144-149.

Ichikawa, H., Takahashi, N., Hieda, S., Ohno, H., Kawamura, M. (2008b). Agraphia in bulbar-onset amyotrophic lateral sclerosis: not merely a consequence of dementia or aphasia. Behavioural Neurology, 20, 91-99.

Ishihara, K., Ichikawa, H., Suzuki, Y., Shiota, J. I., Nakano, I., Kawamura, M. (2010). Is lesion of Exner's area linked to progressive agraphia in amyotrophic lateral sclerosis with dementia? An autopsy case report. Behavioural Neurology, 23, 153-158.

Lucchelli, F., Papagno, C. (2005). Is slowly progressive anarthria a "pure" motor-speech disorder? Evidence from writing performance. Neurocase, 11, 234-241.

Kito, Y., Kazui, H., Yoshida, T., Kubo, Y., Takaya, M., Tokunaga, H., Takeda, M. (2010). Language and semantic memory impairment in a patient with motor neuron disease and semantic dementia: a case report. Brain and Nerve, 62, 625.

Mehrabian, S., Thonberg, H., Raycheva, M., Lilius, L., Stoyanova, K., Forsell, C., Cavallin, L., Nesheva, D., Westman, E., Toncheva, D., Traykov, L. (2018). Phenotypic variability and neuropsychological findings associated with C9orf72 repeat expansions in a Bulgarian dementia cohort. PloS One, 13, e0208383. 
Mioshi, E., Caga, J., Lillo, P., Hsieh, S., Ramsey, E., Devenney, E., Hornberger, M., Hodges, J.R., Kiernan, M.C. (2014). Neuropsychiatric changes precede classic motor symptoms in ALS and do not affect survival. Neurology, 82, 149-155.

Mishima, K., Takeda, K., Nojima, K., Shimizu, T. (2000). A case of agraphia with omitting kana letters-analyzing of process in writing kana words. Shitsugosho Kenkyu (High Brain Funct Res), 20, 280-286.

Moher, D., Liberati, A., Tetzlaff, J., Altman, D. G., Prisma Group. (2009). Preferred reporting items for systematic reviews and meta-analyses: the PRISMA statement. PLoS Medicine, 6, e1000097.

Östberg, P., Bogdanović, N. (2011). Semantic dementia with lower motor neuron disease showing FTLD $\square$ TDP type 3 pathology (sensu Mackenzie). Neuropathology, 31, 271-279.

Pender, N., Pinto-Grau, M., Hardiman, O. (2020). Cognitive and behavioural impairment in amyotrophic lateral sclerosis. Current Opinion in Neurology, 33, 649-654.

Pinto-Grau, M., Hardiman, O., Pender, N. (2018). The study of language in the amyotrophic lateral sclerosis - frontotemporal spectrum disorder: a systematic review of findings and new perspectives. Neuropsychology Review, 28, 251-68.

Piquard, A., Le Forestier, N., Baudoin $\square$ Madec, V., Delgadillo, D., Salachas, F., Pradat, P.F., Derouesné, C., Meininger, V., Lacomblez, L. (2006). Neuropsychological changes in patients with primary lateral sclerosis. Amyotrophic Lateral Sclerosis, 7, 150-160.

Purcell, J., Turkeltaub, P. E., Eden, G. F., Rapp, B. (2011). Examining the central and peripheral processes of written word production through meta-analysis. Frontiers in Psychology, 2, 239. 
Rascovsky, K., Hodges, J.R., Knopman, D., Mendez, M.F., Kramer, J.H., Neuhaus, J., Van Swieten, J.C., Seelaar, H., Dopper, E.G., Onyike, C.U., Hillis, A.E. (2011). Sensitivity of revised diagnostic criteria for the behavioural variant of frontotemporal dementia. Brain, 134, 2456-2477.

Roux, F. E., Dufor, O., Giussani, C., Wamain, Y., Draper, L., Longcamp, M., Démonet, J. F. (2009). The graphemic/motor frontal area Exner's area revisited. Annals of Neurology, 66, 537-545.

Sakurai, Y. (2019). Kanji (Morphogram) and Kana (Phonogram) problem in Japanese Alexia and Agraphia. In J. Bogousslavsky, F. Boller, M. Iwata (Eds.), A History of Neuropsychology (pp. 53-63). Karger Publishers.

Sakurai, Y., Matsumura, K., Iwatsubo, T., Momose, T. (1997). Frontal pure agraphia for kanji or kana: dissociation between morphology and phonology. Neurology, 49, 946-952.

Sakurai, Y., Onuma, Y., Nakazawa, G., Ugawa, Y., Momose, T., Tsuji, S., Mannen, T. (2007). Parietal dysgraphia: characterization of abnormal writing stroke sequences, character formation and character recall. Behavioural Neurology, 18, 99-114.

Sakurai, T., Hirano, S., Abe, M., Uji, Y., Shimizu, K., Suzuki, M., Nakano, Y., Ishikawa, A., Kojima, K., Shibuya, K., Murata, A. (2020). Dysfunction of the left angular gyrus may be associated with writing errors in ALS. Amyotrophic Lateral Sclerosis and Frontotemporal Degeneration, 1-9.

Satoh, M., Takeda, K., Kuzuhara, S. (2009). Agraphia in intellectually normal Japanese patients with ALS: omission of kana letters. Journal of Neurology, 256, 1455-1460.

Shellikeri, S., Myers, M., Black, S. E., Abrahao, A., Zinman, L., Yunusova, Y. (2019). Speech network regional involvement in bulbar ALS: a multimodal structural MRI study. Amyotrophic Lateral Sclerosis and Frontotemporal Degeneration, 20, 385-395. 
Shewan, C. M., Kertesz, A. (1980). Reliability and validity characteristics of the Western Aphasia Battery (WAB). Journal of Speech and Hearing Disorders, 45, 308-324.

Strong, M. J., Abhrahams, S., Goldstein, L. H., Woolley, S., McLaughlin, P., Snowden, J., Mioshi, E., Roberts-South, A., Benatar, M., Hortobagyi, T., Rosenfeld, J., Silani, V., Ince, P. G., Turner, M. R. (2017) Amyotrophic lateral sclerosis- frontotemporal spectrum disorder (ALS-FTSD): revised diagnostic criteria. Amyotrophic Lateral Sclerosis and Frontotemporal Degeneration, 18, 153-154.

Tsuji-Akimoto, S., Hamada, S., Yabe, I., Tamura, I., Otsuki, M., Kobashi, S., Sasaki, H. (2010). Writing errors as a result of frontal dysfunction in Japanese patients with amyotrophic lateral sclerosis. Journal of Neurology, 257, 2071-2077.

Ulugut Erkoyun, H., Groot, C., Heilbron, R., Nelissen, A., van Rossum, J., Jutten, R., Koene, T., van der Flier, W.M., Wattjes, M.P., Scheltens, P., Ossenkoppele, R. (2020). A clinical-radiological framework of the right temporal variant of frontotemporal dementia. Brain, 143, 2831-2843.

Vonk, J.M., Borghesani, V., Battistella, G., Younes, K., DeLeon, J., Welch, A., Hubbard, H.I., Miller, Z.A., Miller, B.L., Gorno-Tempini, M.L. (2020). Verbal semantics and the left dorsolateral anterior temporal lobe: a longitudinal case of bilateral temporal degeneration. Aphasiology, 34, 865-885.

WAB Aphasia Test Construction Committee. (1986). The Japanese version of the Western Aphasia Battery. Tokyo: Igaku-Shoin Ltd.

Watanabe, E. (1893). A patient who manifested cortical motor aphasia concurrently with bulbar and progressive muscular atrophy. Journal of Okayama Medical Association, 40, 13844. 
Woolley, S. C., York, M. K., Moore, D. H., Strutt, A. M., Murphy, J., Schulz, P. E., Katz, J. S. (2010). Detecting frontotemporal dysfunction in ALS: utility of the ALS Cognitive Behavioral Screen (ALS-CBS ${ }^{\mathrm{TM}}$ ). Amyotrophic Lateral Sclerosis, 11, 303-311.

Yabe, I., Tsuji-Akimoto, S., Shiga, T., Hamada, S., Hirata, K., Otsuki, M., Kuge, Y., Tamaki, N., Sasaki, H. (2012). Writing errors in ALS related to loss of neuronal integrity in the anterior cingulate gyrus. Journal of the Neurological Sciences, 315, 55-59.

Zago, S., Poletti, B., Corbo, M., Adobbati, L., Silani, V. (2008). Dysgraphia in patients with primary lateral sclerosis: A speech-based rehearsal deficit?. Behavioural Neurology, 19, $169-175$. 
medRxiv preprint doi: https://doi.org/10.1101/2021.01.31.21250861; this version posted February 1, 2021. The copyright holder for this preprint (which was not certified by peer review) is the author/funder, who has granted medRxiv a license to display the preprint in perpetuity.

It is made available under a CC-BY-NC-ND 4.0 International license
. 
medRxiv preprint doi: https://doi.org/10.1101/2021.01.31.21250861; this version posted February 1, 2021. The copyright holder for this preprint (which was not certified by peer review) is the author/funder, who has granted medRxiv a license to display the preprint in perpetuity.

\section{It is made available under a CC-BY-NC-ND 4.0 International license.}

Figure 1. PRISMA-inspired flow-chart showing study selection process.

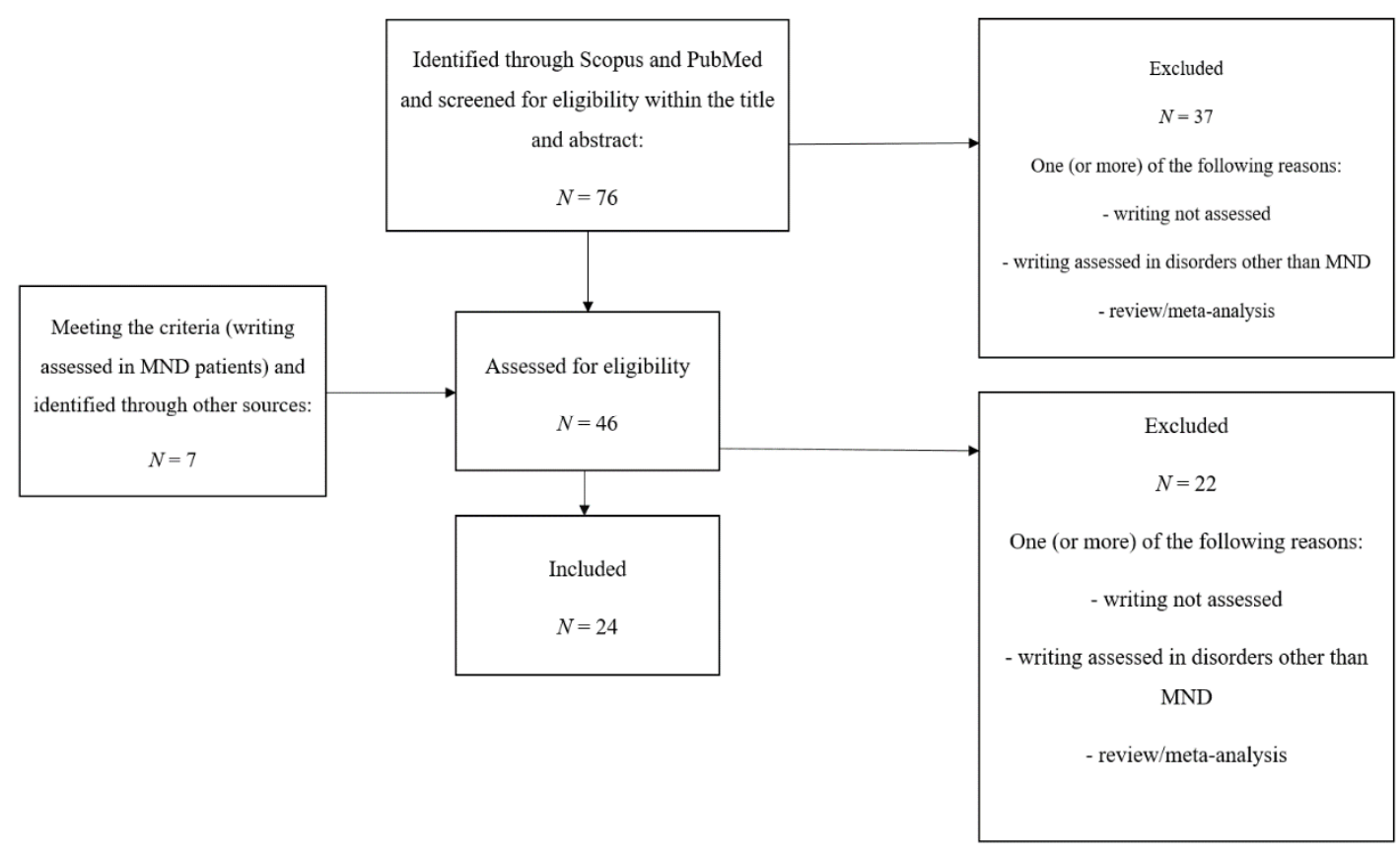

Notes. PRISMA=Preferred Reporting Items for Systematic Reviews and Meta-Analyses; MND=motor neuron disease. 
medRxiv preprint doi: https://doi.org/10.1101/2021.01.31.21250861; this version posted February 1, 2021. The copyright holder for this preprint (which was not certified by peer review) is the author/funder, who has granted medRxiv a license to display the preprint in perpetuity.

It is made available under a CC-BY-NC-ND 4.0 International license .

Table 1. Overview of background outcomes.

\begin{tabular}{|c|c|c|c|c|c|c|c|c|c|c|}
\hline $\begin{array}{c}N \\
\text { pts. }\end{array}$ & Languages & $\begin{array}{c}\text { Age } \\
\text { (y.; } M \text { and } \\
S D \text { range) }\end{array}$ & $\begin{array}{c}\text { Sex } \\
(\mathbf{F} / \mathbf{M})\end{array}$ & $\begin{array}{c}\text { Education } \\
\text { (y.; } M \text { and } S D \\
\text { range })\end{array}$ & $\begin{array}{c}\begin{array}{c}\text { Disease } \\
\text { duration } \\
(\mathrm{mo} ; \boldsymbol{M} \text { and }\end{array} \\
\text { SD range })\end{array}$ & $\begin{array}{c}\text { Phenotype } \\
(N \text { stud.) }\end{array}$ & $\begin{array}{c}\text { ALSFRS-R } \\
(0-48 ; M \text { and } S D \\
\text { range })\end{array}$ & $\begin{array}{c}\text { Bulbar } \\
\text { signs } \\
(N \text { stud. })\end{array}$ & $\begin{array}{c}\text { FTD/ } \\
\text { NPs deficits } \\
(N \text { stud. })\end{array}$ & $\begin{array}{c}\text { NPs/mixe } \\
\text { onset } \\
(N \text { stud. })\end{array}$ \\
\hline$\approx 178$ & $\begin{array}{l}\text { JA.: } 16 \\
\text { IT.:2 } \\
\text { EN.:3 } \\
\text { FR.: } 1 \\
\text { SV.:1 } \\
\text { BG.: } 1\end{array}$ & $\begin{array}{l}41-75 \\
7-12.2\end{array}$ & $81 / 97$ & $\begin{array}{c}5-18 \\
2.13-4.3\end{array}$ & $\begin{array}{c}\text { ALS/MND: } \\
12.3-168 \\
5.1-36 \\
\text { PLS: } \\
49.2-102 \\
24-36\end{array}$ & $\begin{array}{c}\text { ALS:14 } \\
\text { MND:6 } \\
\text { PLS:2 } \\
\text { PBP:1 } \\
\text { LMND:1 }\end{array}$ & $\begin{array}{c}25.3-41.7 \\
4.2-8.4\end{array}$ & 20 & $14 / 8$ & 10 \\
\hline
\end{tabular}

Notes. Abbreviations: pts.=patients; y.=years; EN.=English; FR.=French; IT.=Italian; SV.=Swedish; BG.=Bulgarian; mo.=months; $\mathrm{F}=$ female; $\mathrm{M}=$ male; stud.=studies; $\mathrm{MND}=$ motor neuron disease; ALSFRS-R=ALS Functional Rating Scale - Revised. Summarizations comprise available data only. 
medRxiv preprint doi: https://doi.org/10.1101/2021.01.31.21250861; this version posted February 1, 2021. The copyright holder for this preprint (which was not certified by peer review) is the author/funder, who has granted medRxiv a license to display the preprint in perpetuity.

It is made available under a CC-BY-NC-ND 4.0 International license .

Table 2. Summary of primary and secondary outcomes.

\begin{tabular}{|c|c|c|c|c|c|c|c|c|c|c|c|c|c|c|}
\hline $\begin{array}{l}1^{\text {st }} \text { author, } \\
\text { year }\end{array}$ & $\begin{array}{l}\text { Study } \\
\text { type }\end{array}$ & $N$ & Demog. & $\begin{array}{l}\text { Clinical } \\
\text { features }\end{array}$ & $\begin{array}{c}\text { NPS/ } \\
\text { moto } \\
\mathbf{r} \\
\text { onset }\end{array}$ & FTD & CI/BI & $\begin{array}{c}\text { Oral } \\
\text { LI }\end{array}$ & WA & WI & $\begin{array}{c}\text { Kana } \\
\text { errors }\end{array}$ & $\begin{array}{l}\text { Kanji } \\
\text { errors }\end{array}$ & $\begin{array}{c}\text { Neural } \\
\text { measures }\end{array}$ & $\begin{array}{r}\text { Neu } \\
\text { corre }\end{array}$ \\
\hline $\begin{array}{c}\text { Ferguson, } \\
77\end{array}$ & CS & 2 & $\begin{array}{c}\text { 1:68 y.o. } \\
\text { 2:66 y.o. } \\
\text { EN. } \\
\text { F/M 0/2 }\end{array}$ & $\begin{array}{c}\text { ALS } \\
\text { Bulb.+ }\end{array}$ & motor & no & $\begin{array}{c}\text { 1:Gerst_ } \\
\text { mann } \\
\text { syndrom } \\
\text { e(?) } \\
2: \text { no }\end{array}$ & no & $\begin{array}{l}\text { Writ. nam.; } \\
\text { qual. }\end{array}$ & $\begin{array}{l}\text { 1:synt. err.; } \\
\text { spell. err.; } \\
\text { repetition } \\
\text { of } \mathrm{W} \text { and } \\
\text { phr. } \\
\text { 2:synt. err. }\end{array}$ & - & - & $\begin{array}{l}\text { 1:bil. F,P } \\
\text { (neurop.) }\end{array}$ & - \\
\hline $\begin{array}{l}\text { Hyodo, } \\
{ }^{\prime} 02\end{array}$ & $\mathrm{CR}$ & 1 & $\begin{array}{l}71 \text { y.o. } \\
\text { JA. } \\
\text { F }\end{array}$ & $\begin{array}{l}\text { MND } \\
\text { Bulb.+ }\end{array}$ & $\begin{array}{l}\text { NPS+ } \\
\text { motor }\end{array}$ & PNFA & - & - & $?$ & $\begin{array}{l}\text { Phon. } \\
\text { spell. err.; } \\
\text { synt. err.; } \\
\text { persev. }\end{array}$ & $?$ & $?$ & $\begin{array}{l}\text { l.T+bil. P } \\
\text { (Mo+Fu) }\end{array}$ & - \\
\hline anzaki, ‘04 & $\mathrm{CR}$ & 1 & $\begin{array}{l}55 \text { y.o. } \\
\text { JA. } \\
\text { M }\end{array}$ & $\begin{array}{l}\text { MND } \\
\text { Bulb.+ }\end{array}$ & - & SD & - & - & Dict.; copy & $\begin{array}{c}\text { Copy:OK } \\
\text { Dict.:- }\end{array}$ & $\stackrel{+}{+}$ & + & $1 . \mathrm{T}+\mathrm{F}(\mathrm{Fu})$ & - \\
\hline uchelli, ‘05 & $\mathrm{CR}$ & 1 & $\begin{array}{c}74 \text { y. o. } \\
5 \text { y. edu. } \\
\text { IT. } \\
\text { F }\end{array}$ & $\begin{array}{l}\text { MND. } \\
\text { Bulb.+ }\end{array}$ & NPS & - & $\begin{array}{c}\text { Oro- } \\
\text { facial } \\
\text { apraxia }\end{array}$ & PPAoS & $\begin{array}{c}\text { Writ. nam.; } \\
\text { writ. } \\
\text { compreh. } \\
\text { (W;sent.); } \\
\text { writ. } \\
\text { descript.; } \\
\text { Dict. (W; } \\
\text { N-W); }\end{array}$ & $\begin{array}{l}\text { Morph.- } \\
\text { synt. err.; } \\
\text { omiss.; } \\
\text { subst.;inser } \\
\text { t.;transp. }\end{array}$ & - & - & $\begin{array}{c}\text { 1. F } \\
(\mathrm{Mo}+\mathrm{Fu})\end{array}$ & - \\
\hline $\begin{array}{l}\text { Duffy, } \\
\text { '06 }\end{array}$ & CS & 4 & $\begin{array}{c}\text { age }(\mathrm{y} .)= \\
66.6 \pm 12.2 \\
\text { EN. } \\
\text { F/M } 1 / 3\end{array}$ & $\begin{array}{c}\text { MND } \\
\text { Bulb.+ } \\
\text { DD(mo)= } \\
19.2 \pm 17.6\end{array}$ & $\begin{array}{l}N=1 \\
\text { NPS }\end{array}$ & $\begin{array}{c}N=2 \\
\text { PNFA } \\
N=1 \\
\text { bvFTD } \\
(?)\end{array}$ & - & - & Qual. & $\begin{array}{c}N=4 \\
\text { Spell. err.; } \\
\text { synt.err. }\end{array}$ & - & - & - & - \\
\hline iquard, ‘06 & Group & 20 & $\begin{array}{c}\text { age }(\mathrm{y} .)=63 \\
\pm 8.2 \\
\text { edu. }(\mathrm{y} .)=9 . \\
2 \pm 4.3 \\
\text { FF. } \\
\text { F/M 5/15 }\end{array}$ & $\begin{array}{c}\text { PLS } \\
\text { ALSFRS- } \\
\mathrm{R}=25.3 \pm 5 . \\
9 \\
\mathrm{DD}(\mathrm{y} .)=8 . \\
5 \pm 3.0\end{array}$ & Motor & no & $\begin{array}{c}\mathrm{CI} \\
(\mathrm{EF} ; \mathrm{M})\end{array}$ & no & Dict.: sent. & $\begin{array}{l}\text { Spell. err. } \\
\text { synt. err. }\end{array}$ & - & - & - & - \\
\hline $\begin{array}{c}\text { Zago, } \\
{ }^{\prime} 08\end{array}$ & Group & 16 & $\begin{array}{c}\text { age }(y .)=67 \\
.6 \pm 8.6 \\
\text { edu. }(y)=8 . \\
5 \pm 4.3 \\
\text { IT. } \\
\text { F/M 11/5 }\end{array}$ & $\begin{array}{c}\text { PLS } \\
\text { DD(y.)=4. } \\
1 \pm 2.0 \\
\text { Bulb.+ } \\
(N=7)\end{array}$ & Motor & no & no & $\begin{array}{c}\text { Morph.- } \\
\text { synt.: } \\
\text { PLS } \approx \text { HC: } \\
\text { (normal on } \\
\text { a group lv.; } \\
M= \\
30.75 \pm 4.04 \\
, \\
19-36, \\
\text { c.-o. }=29 \text { ) }\end{array}$ & $\begin{array}{c}\text { Dict.: } \\
\text { W,N-W, } \\
\text { sent.; copy; } \\
\text { W, N-W, } \\
\text { sent; } \\
\text { preformed } \\
\text { let.: W, N- } \\
\text { W) }\end{array}$ & $\begin{array}{c}\text { Copy } \\
\text { PLS=HC } \\
\text { Dict. (W, } \\
\text { N-W, } \\
\text { sent.), } \\
\text { preformed. } \\
\text { let. (N-W): } \\
\text { PLS<HC } \\
\text { Subst;add.; } \\
\text { del.;shift; } \\
\text { exch. }\end{array}$ & - & - & - & - \\
\hline $\begin{array}{l}\text { Satoh, } \\
\quad 09\end{array}$ & CS & 16 & $\begin{array}{c}\text { age }(\mathrm{y} .)= \\
62.9 \pm 9.9 \\
\text { edu.(y): } \\
12.6 \pm 2.13 \\
\text { JA. } \\
\text { F/M 6/10 }\end{array}$ & $\begin{array}{c}\text { ALS } \\
\text { DD(mo)= } \\
15.9 \pm 5.45 \\
\text { ALSFRS- } \\
\text { R: } \\
\text { range= } \\
36-39\end{array}$ & Motor & no & no & - & $\begin{array}{c}\text { Dict.; } \\
\text { copy; } \\
\text { autom. } \\
\text { series; } \\
\text { spont. } \\
\text { writ.; writ. } \\
\text { nam.; }\end{array}$ & $?$ & $\begin{array}{c}N=3 \\
\text { Omiss.; } \\
\text { morae } \\
\text { miscount_ } \\
\text { ing }\end{array}$ & $\begin{array}{c}N=4 \\
+\end{array}$ & $\begin{array}{l}\text { bil. F (Fu) } \\
\qquad(N=1)\end{array}$ & \\
\hline
\end{tabular}


medRxiv preprint doi: https://doi.org/10.1101/2021.01.31.21250861; this version posted February 1, 2021. The copyright holder for this preprint (which was not certified by peer review) is the author/funder, who has granted medRxiv a license to display the preprint in perpetuity.

\section{It is made available under a CC-BY-NC-ND 4.0 International license .}

\begin{tabular}{|c|c|c|c|c|c|c|c|c|c|c|c|c|c|}
\hline & & & & $\begin{array}{c}\text { Bulb.+ } \\
(N=6)\end{array}$ & & & & & $\begin{array}{c}\text { moraic } \\
\text { segmenta_t } \\
\text { ion }\end{array}$ & & & & \\
\hline $\begin{array}{c}\text { Ichikawa, } \\
\text { '08a }\end{array}$ & CS & 7 & $\begin{array}{c}\text { age }(\mathrm{y} .)= \\
63.1 \pm 10.9 \\
\text { JA. } \\
\text { F/M 3/4 }\end{array}$ & $\begin{array}{c}\text { ALS- } \\
\text { FTD(?) } \\
\text { Bulb.+ } \\
(N=6) \\
\text { DD (mo)= } \\
21.29 \pm 12\end{array}$ & $\begin{array}{l}N=3 \\
\text { NPS; } \\
N=4 \\
\text { motor }\end{array}$ & $\begin{array}{c}\text { bvFTD } \\
(?)\end{array}$ & - & $\begin{array}{c}?(N=6 \\
\text { mute; } \\
N=11 \text { non- } \\
\text { aphasic) }\end{array}$ & $\begin{array}{l}N=6 \\
\text { qual. }\end{array}$ & $?$ & $\begin{array}{l}\text { Persev.; } \\
\text { subst.; } \\
\text { omiss.; } \\
\text { synt. err. }\end{array}$ & $\begin{array}{c}\text { Phon./mor } \\
\text { ph.paragra } \\
\text { phias }\end{array}$ & $\begin{array}{c}\text { Bil. F, T } \\
(N=3,>1 .) \\
(\mathrm{Mo}+\mathrm{Fu})\end{array}$ \\
\hline $\begin{array}{c}\text { Ichikawa, } \\
\text { '08b }\end{array}$ & CS & 15 & $\begin{array}{c}\text { age }(y .)= \\
69.3 \pm 8.7 \\
\text { JA. } \\
\text { F/M 7/8 }\end{array}$ & $\begin{array}{c}\text { ALS } \\
\text { DD(mo.)= } \\
18.6 \pm 13.3 \\
\text { Bulb.+ }\end{array}$ & Motor & $\begin{array}{c}N=2 \\
\text { bvFTD } \\
(?)\end{array}$ & $\begin{array}{c}N=10 \\
\text { bv-FTD- } \\
\text { like BI }\end{array}$ & no(?) & Qual. & - & $\begin{array}{c}N=13 \\
\text { omiss.; } \\
\text { subst.;add. } \\
\text { (phon./mor } \\
\text { ph. err.); } \\
\text { synt. err. }\end{array}$ & $\begin{array}{c}N=5 \\
\text { phon./morp } \\
\text { h. err. }\end{array}$ & $\begin{array}{c}\text { Bil. F, T, } \\
\mathrm{P}( \pm)( \pm>1 .)\end{array}$ \\
\hline hihara, ' 10 & $\mathrm{CR}$ & 1 & $\begin{array}{l}73 \text { y.o. } \\
\text { JA. } \\
\text { F }\end{array}$ & $\begin{array}{c}\text { ALS } \\
\mathrm{DD}(\mathrm{mo})= \\
18 \\
\text { Bulb.+ }\end{array}$ & $\begin{array}{l}\text { Motor } \\
+ \text { NPS }\end{array}$ & $\begin{array}{c}\text { bvFTD } \\
(?)\end{array}$ & $+/+$ & $\begin{array}{c}\text { Phon., } \\
\text { lex.-sem., } \\
\text { morph.- } \\
\text { synt. }( \pm)\end{array}$ & $\begin{array}{l}\text { Copy: lett., } \\
\text { sent.; } \\
\text { writ.: W, } \\
\text { sent. }\end{array}$ & $\begin{array}{c}\text { Copy: OK } \\
\text { Persev. } \\
\text { Morph. } \\
\text { dist. }\end{array}$ & $\begin{array}{c}\text { Omiss.;sub } \\
\text { st.;add.; } \\
\text { synt err. }\end{array}$ & + & $\begin{array}{l}\text { Bil a. F,T } \\
\text { (> r.) (Mo, } \\
\text { ), bil. F,T } \\
\text { (Fu); Exner } \\
\text { (neurop.) }\end{array}$ \\
\hline $\begin{array}{c}\text { Kito, } \\
\text { 10 }\end{array}$ & $\mathrm{CR}$ & 1 & $\begin{array}{l}59 \text { y.o. } \\
\text { JA. } \\
\text { M }\end{array}$ & $\begin{array}{l}\text { MND } \\
\text { Bulb.+ }\end{array}$ & $\begin{array}{c}\text { NPS( } \\
?)\end{array}$ & SD & - & - & $\begin{array}{l}\text { Narrative } \\
\text { writ.; dict. }\end{array}$ & $?$ & + & + & $\begin{array}{c}\text { l. T, F } \\
(\mathrm{Mo}+\mathrm{Fu})\end{array}$ \\
\hline $\begin{array}{c}\text { Tsuji- } \\
\text { Akimoto, } \\
\text { '10 }\end{array}$ & Group & 18 & $\begin{array}{c}\text { age }(\mathrm{y})= \\
65.4 \pm 11.5 \\
\text { edu(y.)= } \\
10.8 \pm 2.5 \\
\text { JA. } \\
\text { F/M 9/9 }\end{array}$ & $\begin{array}{c}\text { ALS } \\
\text { DD(mo.)= } \\
19.4 \pm 7 \\
\text { ALSFRS- } \\
\text { R }= \\
34.7 \pm 7.5\end{array}$ & motor & no & $\mathrm{EF} / \mathrm{no}$ & $\begin{array}{l}\text { Morph.- } \\
\text { synt. }\end{array}$ & $\begin{array}{c}N=16 \\
\text { Dict.; writt. } \\
\text { descript. } \\
\text { (WEI) }\end{array}$ & $\begin{array}{l}\text { WEI (synt } \\
\& \text { non- } \\
\text { synt. } \\
\text { err):ALS< } \\
\text { HC }\end{array}$ & $\begin{array}{c}\text { Dict: } N=3+ \\
\text { Writt. } \\
\text { descript.: } \\
\text { non-synt } \\
\text { err.: } \\
\text { omiss., } \\
\text { subst.(PPS) } \\
\text {,displace_ } \\
\text { ment, } \\
\text { incorrect } \\
\text { phonetic } \\
\text { marks, } \\
\text { imperfect } \\
\text { characters; } \\
\text { synt err..: } \\
\text { missing } \\
\text { subjects; } \\
\text { incorrect } \\
\text { conjunct_ } \\
\text { ions/ } \\
\text { postposit_. } \\
\text { ions; } \\
\text { subject- } \\
\text { verb } \\
\text { mismatch; } \\
\text { unfinished. }\end{array}$ & $\begin{array}{c}\text { Dict.: } \\
N=7+ \\
\text { PPS; } \\
\text { morph. }\end{array}$ & - \\
\hline $\begin{array}{c}\text { Ichikawa, } \\
\text { '10a }\end{array}$ & CS & 14 & $\begin{array}{c}\text { age }(y .)= \\
66.9 \pm 11.2 \\
\text { JA. } \\
\text { F/M 6/8 }\end{array}$ & $\begin{array}{l}\text { ALS } \\
\text { Bulb.+ } \\
(N=8)\end{array}$ & $\begin{array}{l}N=1 \\
\text { NPS; } \\
N=13 \\
\text { motor }\end{array}$ & $\begin{array}{c}N=7 \\
\text { bvFTD }\end{array}$ & $\begin{array}{c}N=7 \\
\text { bvFTD- } \\
\text { like BI }\end{array}$ & no(?) & Qual. & & $\begin{array}{c}N=12 \\
\text { Subst.;omi } \\
\text { ss;ins.; } \\
\text { synt err. }\end{array}$ & $\begin{array}{l}N=8 \\
\text { Subst. }\end{array}$ & \\
\hline $\begin{array}{c}\text { Ichikawa, } \\
\text { '10b }\end{array}$ & CS & 2 & $\begin{array}{c}\text { 1:69 y.o. } \\
\text { 2:81 y.o. } \\
\text { JA. } \\
\text { F/M 1/1 }\end{array}$ & $\begin{array}{c}\text { ALS } \\
\text { Bulb.+ }\end{array}$ & motor & no & no & no & Qual.;dict. & - & $\begin{array}{l}\text { Omiss.; } \\
\text { subst. } \\
\text { synt. err }\end{array}$ & $\begin{array}{c}\text { Subst.; } \\
\text { transposit. }\end{array}$ & $\begin{array}{c}\text { 1:Bil. F,T } \\
\text { (> 1.) (Fu); } \\
\text { bil F. } \\
\text { (Mo) } \\
\text { 2: bil. F-T, } \\
\text { P (>l.) } \\
\text { (Fu); } \\
\text { diffuse } \\
\text { atrophy } \\
\text { (Mo) }\end{array}$ \\
\hline
\end{tabular}

Bulb.+
$(N=6)$
CS 
medRxiv preprint doi: https://doi.org/10.1101/2021.01.31.21250861; this version posted February 1, 2021. The copyright holder for this preprint (which was not certified by peer review) is the author/funder, who has granted medRxiv a license to display the preprint in perpetuity.

\section{It is made available under a CC-BY-NC-ND 4.0 International license.}

\begin{tabular}{|c|c|c|c|c|c|c|c|c|c|c|c|c|c|c|}
\hline $\begin{array}{c}\text { Ichikawa, } \\
\text { '11b }\end{array}$ & $\mathrm{CR}$ & 1 & $\begin{array}{c}41 \text { y.o. } \\
\text { JA. } \\
\text { M }\end{array}$ & $\begin{array}{l}\text { MND(?) } \\
\text { Bulb+ }\end{array}$ & Motor & $\begin{array}{l}\text { PPA/bv } \\
\text { FTD(?) }\end{array}$ & - & - & $\begin{array}{c}\text { Qual.; } \\
\text { writt. } \\
\text { answer; } \\
\text { dict.; copy; } \\
\text { syllables } \\
\text { counting; } \\
\text { writ. of } \\
\text { automated } \\
\text { series }\end{array}$ & $\begin{array}{l}\text { Copy, writ. } \\
\text { of } \\
\text { automated } \\
\text { series: OK } \\
\text { Writt. } \\
\text { answer, } \\
\text { dict: - } \\
\text { syllables } \\
\text { counting: - }\end{array}$ & + & $\begin{array}{c}\text { Phon./mor } \\
\text { ph./sem. } \\
\text { err.; }\end{array}$ & - & - \\
\hline Istberg, '11 & $\mathrm{CR}$ & 1 & $\begin{array}{c}63 \text { y.o. } \\
\text { SV. } \\
\text { M }\end{array}$ & $\begin{array}{l}\text { LMND } \\
\text { Bulb.+ }\end{array}$ & NPS & SD & - & - & Qual. & $\begin{array}{c}\text { Lexical } \\
\text { agraphia }\end{array}$ & - & - & $\begin{array}{c}\text { Bil. T( } \\
\text { r.>l.) } \\
\text { (Mo.+Fu+n } \\
\text { europath.) }\end{array}$ & - \\
\hline $\begin{array}{l}\text { Yabe, } \\
' 12\end{array}$ & Group & 10 & $\begin{array}{c}\text { age(y.) }= \\
61.1 \pm 11.7 \\
\text { JA. } \\
\text { F/M 4/6 }\end{array}$ & $\begin{array}{c}\text { ALS } \\
\text { DD(mo.)= } \\
19.1 \pm 5.1 \\
\text { ALSFRS- } \\
\text { R= } \\
35.6 \pm 8.4\end{array}$ & Motor & no & $\mathrm{EF}( \pm) /-$ & no & $\begin{array}{c}\text { Writ. } \\
\text { descript. } \\
\text { (WEI) }\end{array}$ & $\begin{array}{c}\text { WEI:ALS< } \\
\text { HC }\end{array}$ & $?$ & $?$ & - & $\begin{array}{r}\text { WEI rt } \\
\text { to } \mathrm{t} \\
\text { ante } \\
\text { cingu } \\
\text { corl } \\
\text { atrol } \\
( \pm r .>1 .\end{array}$ \\
\hline $\begin{array}{c}\text { Maeda, } \\
\text { '15 }\end{array}$ & $\mathrm{CR}$ & 1 & $\begin{array}{c}68 \text { y.o. } \\
\text { JA. } \\
\text { F }\end{array}$ & $\begin{array}{c}\text { PBP } \\
\text { Bulb.+ }\end{array}$ & motor & $\begin{array}{l}\text { bvFTD( } \\
?)\end{array}$ & - & no & $\begin{array}{c}\text { Qual.; } \\
\text { writ./dict. } \\
\text { :let., W, } \\
\text { sent.; } \\
\text { mobile } \\
\text { texting }\end{array}$ & $\begin{array}{l}\text { Writ./dict. } \\
\text { lett.: OK } \\
\text { Writ./dict. } \\
\text { W, sent.: - }\end{array}$ & $\begin{array}{c}+ \\
\text { Omiss.;sub } \\
\text { s.; synt. } \\
\text { err. }\end{array}$ & \pm & $\begin{array}{l}\text { Bil. F, r. P } \\
\text { (Fu) }\end{array}$ & - \\
\hline$\underset{\cdot 16}{\text { Cui, }}$ & $\mathrm{CR}$ & 1 & $\begin{array}{c}67 \text { y.o. } \\
6 \text { y. edu. } \\
\text { JA. } \\
\text { F }\end{array}$ & $\begin{array}{c}\text { ALS } \\
\text { Bulb.+ }\end{array}$ & motor & $\begin{array}{l}\text { bvFTD }( \\
?)\end{array}$ & - & $\operatorname{no}( \pm)$ & $\begin{array}{c}\text { Dict.;writ. } \\
\text { nam.;copy; } \\
\text { autom. } \\
\text { series; } \\
\text { spont. writ. }\end{array}$ & $\begin{array}{c}\text { Dict.+writt } \\
\text {. nam.: } \\
\text { phon. } \\
\text { subst.; } \\
\text { add.; } \\
\text { omiss.; } \\
\text { morph. err. } \\
\text { Copy: OK }\end{array}$ & - & - & $\begin{array}{l}\text { r. } \mathrm{T}, \pm \text { bil. F } \\
\text { and } 1 . \mathrm{T}\end{array}$ & - \\
\hline $\begin{array}{l}\text { Aehrabian, } \\
\quad 18\end{array}$ & $\mathrm{CR}$ & 1 & $\begin{array}{l}50 \text { y.o. } \\
11 \text { y. edu. } \\
\text { BG. } \\
\text { M }\end{array}$ & $\begin{array}{c}\text { ALS-FTD } \\
\mathrm{DD}(\mathrm{y} .)=4 \\
\text { Bulb.+ }\end{array}$ & NPS & $\begin{array}{l}\text { bvFTD( } \\
?)\end{array}$ & - & no & Writ. nam. & $\begin{array}{l}\text { Subst.; } \\
\text { omiss. }\end{array}$ & - & - & $\begin{array}{c}\mathrm{F}(>1 .), \\
\text { hippocamp } \\
\text { us }\end{array}$ & - \\
\hline akurai, '20 & Group & 37 & $\begin{array}{c}\text { age(y.)=69 } \\
.9 \pm 9.2 \\
\text { edu. }(y .)=1 \\
2 \pm 2.7 \\
\text { JA. } \\
\text { F/M 20/17 }\end{array}$ & $\begin{array}{c}\text { ALS } \\
\text { DD }(\text { mo. })= \\
13.6 \pm 8.9 \\
\text { ALSFRS- } \\
\text { R=37.8 } \pm 7 . \\
6\end{array}$ & Motor & - & - & $\begin{array}{l}\text { Phon., } \\
\text { lex.-sem., } \\
\text {,morph.- } \\
\text { synt.,conne } \\
\text { cted } \\
\text { speech } \\
( \pm)\end{array}$ & $\begin{array}{c}\text { Writ. } \\
\text { descript. }\end{array}$ & - & $\begin{array}{l}\text { Omiss.; } \\
\text { subst.; } \\
\text { incorrect } \\
\text { phonetic } \\
\text { marks }\end{array}$ & - & $\begin{array}{l}\text { Bil. F-P } \\
\text { (Fu.) }\end{array}$ & $\begin{array}{r}\text { Wr } \\
\text { desc } \\
\text { relatec } \\
\text { AG }(\end{array}$ \\
\hline Vonk, '20 & $\mathrm{CR}$ & 1 & $\begin{array}{c}67 \text { y.o. } \\
18 \text { y. edu. } \\
\text { EN } \\
\text { F }\end{array}$ & $\begin{array}{c}\text { ALS } \\
\mathrm{DD}(\mathrm{y} .)=14\end{array}$ & NPS & SD & - & - & $?$ & $\begin{array}{c}\text { Surface } \\
\text { dysgraphia }\end{array}$ & - & - & $\begin{array}{l}\text { Bil. F; bil. } \\
\text { T (r.->1.) }\end{array}$ & - \\
\hline
\end{tabular}


Iotes. Abbreviations: Demog.=demographics; NPS=neuropsychological; FTD=frontotemporal degeneration; CI=cognitive impairment; BI=behavioral impairmer I=language impairment; WA=writing assessment; WI=writing impairment; $\mathrm{CR}=$ case report; $\mathrm{CS}=$ case series; edu.=education; $\mathrm{y} .=\mathrm{years}$; y.o.=years old; mo.=mon I=male; F=female; EN.=English; FR.=French; IT.=Italian; SV.=Swedish; BG.=Bulgarian; MND=motor neuron disease; ALS=amyotrophic lateral sclerosis;

$\mathrm{LS}=$ primary lateral sclerosis; $\mathrm{LMND}=$ lower motor neuron disease; $\mathrm{PBP}=$ progressive bulbar palsy; $\mathrm{DD}=$ disease duration; Bulb.+=presence of bulbar signs; ALSF $:=$ Amyotrophic Lateral Sclerosis Functional Rating Scale - Revised; bvFTD=behavioral variant of frontotemporal dementia; PNFA=progressive non-fluent apha: $\mathrm{D}=$ semantic dementia; PPAoS=primary progressive apraxia of speech; EF=executive functioning; M=memory; phon.=phonological; lex.-sem.=lexico-semantic; orph.-synt.=morpho-syntactic; qual.=qualitative; writ. nam.=written naming; dict.=dictation; $\mathrm{W}=$ word; $\mathrm{N}-\mathrm{W}=$ non-word; sent.=sentence; spont. writ.=spontaneor rriting; autom.=automatic; writ. descript.=written description; WEI=writing error index; $\mathrm{HC}=$ healthy control; spell. err.=spelling error; synt. err.=syntactic error; ynt. err.=non-syntactic error; subst. $=$ substitution; omiss. $=$ omission; add. $=$ addition; dist. $=$ distortion; ins. $=$ insertion; persev. $=$ perseveration; morph. err. $=$ morpholog rror; PPS=phonologically-plausible substitution; bil.=bilateral; $\mathrm{F}=$ frontal; $\mathrm{T}=$ temporal; $\mathrm{P}=$ parietal; $\mathrm{Mo}=$ morphological (imaging); $\mathrm{Fu}=$ functional (imaging); $\mathrm{r}$ =rig =left; neurop.=neuropathological (examination); $\mathrm{AG}=$ angular gyrus. When there was a suspect/confirmation of dementia (column "FTD"), the columns "CI/BI" nd/or "oral LI" were not filled. 